\title{
Organizational Role Stress of Customer Service Representatives (On Desk) and its relationship with their level of Emotional Intelligence
}

\author{
R. Shah, P. Maheshwari \\ India
}

\begin{abstract}
The present study aimed at finding out the level of Organizational role stress and Emotional Intelligence in Customer Service Representatives $(C S R)$ and the relationship between the two. The sample comprised of 60 CSR's working in different sectors-travel, private banks and mobile networks, having an 8 hr job. Non-probability sampling was used to select the sample. Self constructed scales to measure Emotional Intelligence and Organizational role Stress were administered on the selected participants. The data was supported with qualitative information acquired through an interview schedule. Findings revealed that majority of the CSR's (41) perceived themselves as below average to average in their levels of emotional intelligence, average to above average level of role stress (45). Further the results revealed a significantly high negative correlations between the level of Organizational role stress and Emotional intelligence $(r=-.868 * *$, $p=.000$ ). The findings of the study have a clear implication for the organization, especially for the Human Resource departments who can set up training programs and workshops facilitating the CSR's to develop and practice emotional intelligence competencies and reduce their role stress thereby improving their job performance by providing excellent and satisfying customer service.
\end{abstract}

\section{Introduction}

According to Goleman, "If your emotional abilities aren't in hand, if you don't have selfawareness, if you are not able to manage your distressing emotions, if you can't have empathy and have effective relationships, then no matter how smart you are, you are not going to get very far". Salovey and Mayer have explained the concept of Emotional Intelligence [19]. They state that even when an individual has a perfect job in hand with great salary, tremendous growth opportunities and ideal location, there is a possibility where he would resign. In such instances an individual would make decisions based on logic or only feelings or both. Solving problems and making decisions considering both thoughts or logic and feelings or intuition is what is referred to as Emotional Intelligence (as cited in Rivers and Salovey, 2010).

According to The Center for Creative Leadership, (1994), "75\% of careers are derailed for reasons related to emotional competencies, including inability to handle interpersonal problems; unsatisfactory team leadership during times of difficulty or conflict; or inability to adapt to change or elicit trust." (http://www.susandunn.cc/emotional_intelligence_qu otations.htm).

Customer Service is considered as an important part of any business today. "To thrive, excellence in technology, quality and customer service along with cost competitiveness is a prerequisite" [12]. The cost of retaining customers is much lower than acquiring new ones. Acquiring new customers is important, but holding on to existing customers is crucial. Old customers spend 33\% more than new customers. Referrals by the old customers are $107 \%$ greater than new customers. It costs $6 \%$ more to sell something to a prospect than to sell that same thing to an existing customer. So one can see the need for a consistent and committed customer support services that will nurture and strengthen this bond.

A lost credit card, a cancelled flight, investment advice, mobile bill queries etc are moments when a customer invests a high amount of emotional energy for an outcome. Skilful handling of these moments requires a frontline employee that puts the customer's emotional needs ahead of the company's and his own agendas and at the same time keeps his emotions under control [3]. Every time the customers have to wait on hold for an hour, or are told different things by different representatives, or receive defective support, or simply don't get their issues resolved, it affects not that one interaction, but the relationship with that customer is affected and the customer might choose to switch to some other brand [21]. If the emotional intelligence of these CSR's is high, it can be sure that most of those moments would result in a positive outcome [3].

Coscia and D'Ausilo argue that customer service position is of the ten most stressful jobs in today's economy. Role Stress affects customer service [8]. According to Greg Coleman [7], "We are at the mercy of our emotions in the support center, largely due to the stressful circumstances inherent in providing customer service". Call centers are 
providing jobs to a large number of young men and women in India. In spite of good salaries and facilities for employees this sector has high turn-over rate. This is because of Role Stress. The primary source of stress here lies in the inherent nature of the job which include spending hours on the phone; dealing with people on a continuous basis, and working under constant pressure to deliver quality service along with volumes on calls. They do not have the liberty to get off the phone and often have no time to recover from an awkward call or customer rejection in person [13].

Work can get frustrating, especially when dealing with irritating and abusive customers. The employees have been reporting the symptoms of mental and physical ill health such as nervousness, chronic fatigue, body ache, insomnia, nausea, anxiety, restlessness, irritability and even depression [2]. All these conditions may be the result of stress. "Stress is definitely a factor. When an individual is stressed, his cognitive brain shuts down, which decreases problem solving and cognitive thinking, so one can't solve the customer's problem. Also, one may experience an amygdala hijack where emotions take over" [9]. "Through emotional self awareness, stress tolerance, self actualization, happiness and optimism, you create resilience. That way, when stressful things happen, you can cope with them in a positive way. If these five areas are low on the EQi, it is a burnout indicator and there can be problems with performance, illnesses etc" [9]. Thus an important aspect of Emotional Intelligence is to help the individual deal with stress which eventually leads to success and profit for the organization [20].

The present study aimed at finding out the level of organizational role stress in customer service representatives and its interrelationship with the level of emotional intelligence among the CSR's.

\section{Methods}

\subsection{Sample}

The sample consisted of 60 employees working in the customer service department of different industry (like travel, mobile networks, banks), having an $8 \mathrm{hr}$ (9am to 5pm) job. They belonged to nuclear families with minimum qualification being HSC. The minimum age of the employee's being 18years, with an experience of 1 to 3 years in the present job. Judgmental/ purposive or non-probability sampling was used to select the sample.

\subsubsection{Tools used}

\section{A. Self - constructed emotional intelligence scale}

The tool was based on framework of Goleman and Boyatizis that covered four main domains: self awareness, self management, social awareness and relationship management and twenty-one sub domains of emotional intelligence [11]. The number of items under each sub domain was not equal as the number of skills representing each sub domain was varied. The items were made keeping in mind their relevance to the customer service setting. The scale consisted of 108 items out of which 68 items were positive while 40 items needed to be scored reversely. Each item was rated on a 1-5 point rating scale where 1 represented to a very small extent and 5-To a very large extent. The minimum obtainable score was 108 and maximum score was 540. Reliability analysis using Cronbach's Alpha of this scale was .985 (high internal consistency).

\section{B. Self-constructed role stress scale}

The tool comprised of 52 items. The items in the test tapped 10 dimensions which were: Self Role Distance (6 items), Inter Role Distance (4 items), Role Stagnation (6 items), Role Isolation (4 items), Role Ambiguity (5 items), Role Expectation Conflict (5 items), Role Overload (6 items), Role Erosion (4 items), Resource Inadequacy (6 items) and Personal Inadequacy (5 items). The number of items under each domain was not equal. A 5-point rating scale was used where 1 indicated 'To a very small extent' and 5 indicated 'To a very large extent', primarily to avoid socially relevant answers. The minimum score was 52 and maximum score was 260. Reliability analysis was done using Cronbach's Alpha and this tool was found to have high internal consistency (alpha= .983).

\section{Self constructed interview schedule.}

It had two sections: one on EI and the other on organizational role stress. Questions were framed to gather qualitative data on the two sections. These questions gathered information with regard to the perceived EI skills that are required for the job of a CSR and the major stressors experienced in the role of a CSR. 


\section{Results}

In order to measure the level of role stress in the customer service representatives (on desk/ frontline), a self constructed Organizational role stress scale (based on the Organizational role stress scale of Pareek [16]) was used. Out of the 60 participants, 30 participants reported above average level of role stress. The mean score of the participants on the scale, also fell above the theoretical midpoint clearly indicating that majority of participants were experiencing stress in relation to their role [Refer to Table 1]

Table 1. Frequencies of participants in different Levels of Role Stress $(\mathrm{N}=60)$

\begin{tabular}{|l|l|}
\hline Categories & $F$ \\
\hline Well below average & 7 \\
\hline Below average & 8 \\
\hline Average & 15 \\
\hline Above average & 21 \\
\hline Well above average & 9 \\
\hline
\end{tabular}

On emotional intelligence scale, majority of participants perceived themselves as having average (22) or below average (19) level of EI [Refer to Table 2]

Table 2. Frequencies of participants in different Levels of Emotional Intelligence $(\mathrm{N}=60)$

\begin{tabular}{|l|l|}
\hline Categories & $F$ \\
\hline Well below average & 0 \\
\hline Below average & 19 \\
\hline Average & 22 \\
\hline Above average & 19 \\
\hline Well above average & 0 \\
\hline
\end{tabular}

A significant negative strong correlation was found between the perceived level of emotional intelligence and perceived organizational role stress $(r=-.868$, $\mathrm{p}=0.000$ ) [Refer to Table3], thereby, indicating that higher the perceived level of emotional intelligence, lower was the level of role stress perceived.

Further, correlations were computed between the domains of emotional intelligence and the domains of organizational role stress. It was found that each domain of emotional intelligence (self awareness, self management, social management and relationship management) had a significant negative strong correlation with all the domains of role stress, i.e., inter-role distance, role stagnation, role-expectation conflict, role erosion, role overload, role isolation, role ambiguity, self-role distance, personal inadequacy, resource inadequacy (see Table 4). It was interesting to note that in comparison to other domains of EI, social management had higher correlation values across the eight domains of EI indicating that lower on empathy, service orientation and organizational awareness, higher the perceived level of stress (see Table 4).

Table 3. Relationship between the level of emotional intelligence and the level of organizational role stress $(\mathrm{N}=60)$

\begin{tabular}{|l|l|l|}
\hline \multirow{2}{*}{$\begin{array}{l}\text { emotional } \\
\text { intelligence }\end{array}$} & $\begin{array}{l}\text { Organizational role } \\
\text { stress } \\
\text { Correlation }\end{array}$ & $-.868 * *$ \\
\cline { 2 - 3 } & Sig. (2-tailed) & .000 \\
\cline { 2 - 3 } & $\mathrm{N}$ & 60 \\
\hline
\end{tabular}

According to majority of respondents (39), emotional skills were required for customer service representative whereas some respondents (21) were of the opinion that emotional skills were not important to be a successful customer service representative. According to respondents who said that emotional skills are required, communication was chosen by majority of respondents (19) followed by relationship building chosen by 12 respondents and confidence chosen by 11 respondents. Some of the other skills given by respondents were being polite, convincing power, understanding customer requirements, trust, problem solving, assertiveness, positivity and handling frustration. Of these, majority skills/competencies (43) fell into the relationship domain followed by 26 skills into the self management domain of EI .When participants rated themselves on the EI scale, they perceived themselves to be low on these domains where the mean fell below the theoretical midpoint. Some of the respondents (21) who said that emotional skills were not required, they listed few other skills which they thought were required like intelligence (4), proper knowledge/information (4), quick thinking (3), clarity (3), system operation (1) and professionalism (1). 
Table 4. Relationship between domains of EI and domains of organizational role stress (N=60)

\begin{tabular}{|c|c|c|c|c|c|c|c|c|c|c|}
\hline & $\begin{array}{l}\text { Inter-role } \\
\text { Distance }\end{array}$ & $\begin{array}{l}\text { Role } \\
\text { Stagnation }\end{array}$ & $\begin{array}{l}\text { Role- } \\
\text { expectation } \\
\text { conflict }\end{array}$ & $\begin{array}{l}\text { Role } \\
\text { Erosio } \\
\mathrm{n}\end{array}$ & $\begin{array}{l}\text { Role } \\
\text { Overload }\end{array}$ & $\begin{array}{l}\text { Role } \\
\text { Isolation }\end{array}$ & $\begin{array}{l}\text { Selfrole } \\
\text { Distance }\end{array}$ & $\begin{array}{l}\text { Role } \\
\text { ambiguit } \\
\text { y }\end{array}$ & $\begin{array}{l}\text { Personal } \\
\text { Inadequacy }\end{array}$ & $\begin{array}{l}\text { Resource } \\
\text { Inadequacy }\end{array}$ \\
\hline \multicolumn{11}{|l|}{$\begin{array}{l}\text { Self } \\
\text { awareness }\end{array}$} \\
\hline $\begin{array}{l}\text { Pearson } \\
\text { Correlation }\end{array}$ & $-.764(* *)$ & $-.700(* *)$ & $-.781(* *)$ & $\begin{array}{l}- \\
.687(* \\
*)\end{array}$ & $-.779(* *)$ & $.750(* *)$ & $-786(* *)$ & $-.730(* *)$ & $-.789(* *)$ & $-.764(* *)$ \\
\hline $\begin{array}{l}\text { Sig. (2- } \\
\text { tailed) }\end{array}$ & .000 & .000 & .000 & .000 & .000 & .000 & .000 & .000 & .000 & .000 \\
\hline $\mathrm{N}$ & 60 & 60 & 60 & 60 & 60 & 60 & 60 & 60 & 60 & 60 \\
\hline \multicolumn{11}{|l|}{$\begin{array}{l}\text { Self } \\
\text { management }\end{array}$} \\
\hline $\begin{array}{l}\text { Pearson } \\
\text { Correlation }\end{array}$ & $-.797(* *)$ & $-.762(* *)$ & $-.829(* *)$ & $\begin{array}{l}- \\
.762(* \\
*)\end{array}$ & $-.834(* *)$ & $-.785(* *)$ & $-837(* *)$ & $-.774(* *)$ & $-.845(* *)$ & $-.828(* *)$ \\
\hline $\begin{array}{l}\text { Sig. (2- } \\
\text { tailed) }\end{array}$ & .000 & .000 & .000 & .000 & .000 & .000 & .000 & .000 & .000 & .000 \\
\hline $\mathrm{N}$ & 60 & 60 & 60 & 60 & 60 & 60 & 60 & 60 & 60 & 60 \\
\hline \multicolumn{11}{|l|}{$\begin{array}{l}\text { Social } \\
\text { management }\end{array}$} \\
\hline $\begin{array}{l}\text { Pearson } \\
\text { Correlation }\end{array}$ & $-.807(* *)$ & $-.769(* *)$ & $-.847(* *)$ & $\begin{array}{l}- \\
.740(* \\
*)\end{array}$ & $-.830(* *)$ & $-.803(* *)$ & $.860(* *)$ & $-.795(* *)$ & $-.825(* *)$ & $-.824(* *)$ \\
\hline $\begin{array}{l}\text { Sig. (2- } \\
\text { tailed) }\end{array}$ & .000 & .000 & .000 & .000 & .000 & .000 & .000 & .000 & .000 & .000 \\
\hline $\mathrm{N}$ & 60 & 60 & 60 & 60 & 60 & 60 & 60 & 60 & 60 & 60 \\
\hline \multicolumn{11}{|l|}{$\begin{array}{l}\text { Relationship } \\
\text { management }\end{array}$} \\
\hline $\begin{array}{l}\text { Pearson } \\
\text { Correlation }\end{array}$ & $-.781(* *)$ & $-.738(* *)$ & $-.802(* *)$ & $\begin{array}{l}- \\
.703(* \\
*)\end{array}$ & $-.791(* *)$ & $-.740(* *)$ & $\begin{array}{l}- \\
.797(* *)\end{array}$ & $-.722(* *)$ & $-.762(* *)$ & $-.783(* *)$ \\
\hline $\begin{array}{l}\text { Sig. (2- } \\
\text { tailed) }\end{array}$ & .000 & .000 & .000 & .000 & .000 & .000 & .000 & .000 & .000 & .000 \\
\hline $\mathrm{N}$ & 60 & 60 & 60 & 60 & 60 & 60 & 60 & 60 & 60 & 60 \\
\hline
\end{tabular}

**coorelation is significant at the 0.01 level ( 2 tailed)

The reasons for why emotional skills were important for this role, got answers like 'because there is constant interaction with customers', 'to reduce stress', 'to decrease conflicts' and 'to handle different types of people' (see Table 5)..

Respondents were also asked about the stresses they encounter while working as a customer service representative. These responses were then classified into the ten domains of organizational role stress. Most of the participants (45) said that they experienced stress in this role. Some of the stressors they listed were monotonous nature of job, meeting targets pressure / deadlines, Shift timing / rotational shift, abusive clients, no time for family/ social life, multiple clients at time, conversation with clients, maintaining relations with customer and language of client. Majority (41) responses fell in the role overload domain followed by role stagnation domain with 16 responses and role expectation conflict domain with 11 responses thus indicating that majority of CSR's found their role stressful because they experienced overload in the role or they 
perceived themselves as stagnated in their role. [Refer to table 6].

Table 5. The EI skills that are perceived as important by CSR and their frequencies $(\mathrm{N}=60)$

\begin{tabular}{|l|l|}
\hline Yes responses (n=39) & 13 \\
\hline $\begin{array}{l}\text { Self awareness (confidence, controlling } \\
\text { anger/frustration) }\end{array}$ & 26 \\
\hline $\begin{array}{l}\text { Self management (thinking in a positive } \\
\text { manner, trust, commitment) }\end{array}$ & 10 \\
\hline $\begin{array}{l}\text { Social management (empathy, helping the } \\
\text { clients, listening effectively) }\end{array}$ & 43 \\
\hline $\begin{array}{l}\text { Relationship management (communication, } \\
\text { problem solving, handling clients tactfully, } \\
\text { conflict management, convincing power) }\end{array}$ & 3 \\
\hline No responses (n=21) & 1 \\
\hline Quick thinking & 1 \\
\hline Social Attachment & 5 \\
\hline Professionalism & 3 \\
\hline Proper knowledge/information & 1 \\
\hline Clarity & 7 \\
\hline System Operation & \\
\hline Intelligence (no emotions). & \\
\hline
\end{tabular}

Table 6. Frequencies of responses in relation to the reasons for why the role of a CSR is stressful $(\mathrm{N}=60)$

\begin{tabular}{|l|l|}
\hline Stressors (yes= 45) & $f$ \\
\hline $\begin{array}{l}\text { Role overload (meeting deadlines, targets, } \\
\text { dealing with multiple clients at a time, have to } \\
\text { be updated with new information) }\end{array}$ & 41 \\
\hline $\begin{array}{l}\text { Role stagnation (no growth opportunities, } \\
\text { monotonous job }\end{array}$ & 16 \\
\hline $\begin{array}{l}\text { Role expectation conflict (maintaining } \\
\text { relationship with client, even you don't want } \\
\text { to) }\end{array}$ & 11 \\
\hline $\begin{array}{l}\text { Inter-role distance (no time to socialize with } \\
\text { family and friends, due to shift changes) }\end{array}$ & 10 \\
\hline Self role distance (cannot relate to the job) & 4 \\
\hline Personal inadequacy (no proper training, skills) & 3 \\
\hline $\begin{array}{l}\text { Resource inadequacy (noisy atmosphere, faulty } \\
\text { system operating machines) }\end{array}$ & 3 \\
\hline (No=15) & $f$ \\
\hline Money & 7 \\
\hline Supervisor is helpful & 5 \\
\hline Duty to do the job & 3 \\
\hline
\end{tabular}

\section{Discussion}

"Smart innovative brand is represented by smart innovative people. Ex: Apple-The brand is smart, but their Customer service is smarter! Customer service is actually a part of brand promise. Therefore, here customer service becomes very important. You as organizations do not want to become one in a million." (personal face to face communication, Freedman, September 23, 2011). They not only have plenty of frontline staff, but do they have helpful, engaged, fun, and knowledgeable employees [5]. This could be attributed as one of the major reasons why apple as a brand has fan followers who are loyal and happy! A customer on the consumer court forum had complained, "I have not been able to receive SMS from a particular number. I went to customer care to file a complaint. Miss $X$ attended me. When I told her about my issue she said the network is down, come after $1 \mathrm{pm}$. I again called up and some guy picked up the call, when I asked his name he refused. I asked him to connect me to his immediate boss, but he put me on hold for half an hour and then said $i$ will have to wait for some more time. This is the worst customer service that I've seen in my life. Rather than customer care service it should be named customer embarrassment service. I don't know whether they don't understand English or they are not well trained or they are not qualified enough. Whatever be the reason its impacted me so negatively that I am not going to use $Y$ communication ever again in my life."

(http://www.consumercourtforum.in/f49/complaintagainst-reliance-communication-their-customer-caredept-16477/ ). This is a clear illustration of how lack of EI skills like empathy, communication, conflict management, on the part of the customer service providers lead to frustration and dissatisfaction among their clients as well as gives them opportunity to tell their friends, family and colleagues about the negative experience they have encountered, thus convincing them to switch over from that organization/brand as well [4].

A study done in the United States across 784 call centers has concluded that on a scale of 1 through 10 (Ten being highest) a whopping $32 \%$ of customer service representatives rate their stress level at 10 , while the majority averaged a stress level of 7 . (http://www.customerservicepoint.com/relief-

stress.html). According to Jeff Crouse, a call center employee who has done a course in EI "The biggest stress I can remember would be dealing with a lot of customer's at one time (e.g. having calls waiting, unhappy customers, etc.)" (Personal communication, via e-mail, July 29, 2011). Thus, Managing stress is an essential job skill for the successful customer service professional. Typically customer service representatives experience burnout from two sources: 1) repetitive routine requests, and 2) frustrated customers. The combination can lead to stress, unless the representatives manage their responses well. (http://www.donnaearltraining.com/Articles/StressM anagementTips.html).

As observed in the results, a significant negative strong correlation was found between the perceived level of emotional intelligence and perceived 
organizational role stress $(r=-.868, p=0.000)$ of the CSR's indicating that lower the EI, higher the perceived role stress. In a study by Oginska et al., the results confirmed an essential, but not very strong, role of emotional intelligence in perceiving role stress and preventing employees of human services from negative health outcomes [14]. They concluded that when an individual effectively deals with emotions and emotional information in the workplace, he/she is better able to cope with role stress. The job profile of a CSR itself demands that the CSR be high on the emotional skill. If the CSR is low on this skill, he/ she will have difficulty dealing with abusive/ aggressive clients. The CSR might also avoid facing the conflict .They would then focus on the customer rather than the issue and with hold bad feelings about a negative interaction that he/she has had with the customer. "Eventually all these negative feelings get bottled up which would harm the CSR both emotionally and physically". (Jeff, CSR, personal communication via email, 2011). According to RoopRai and Kumar [18], emotional intelligence correlates negatively with stress and anxiety, and it is also predicted through levels of Stress and Anxiety thus indicating that low or high levels of EI, to some extent certainly establish a relationship with both stress and anxiety (http://asbbs.org/files/2009/PDF/R/Rooprai.pdf). In case of job of a CSR the strong negative relationship between the two is justified, because there is an inherent demand of the job to handle multiple clients, different moods of the customers, meeting the constantly changing demands of the clients etc and thus as discussed earlier, the competencies of adaptability, empathy, initiative, communication, building bonds, conflict management (EI competencies) etc are highly needed to be effective and for providing quality customer services and satisfaction to the clients. Green also found that the successful CEO's and senior managers in Australia had high levels of EI in comparison to the general workforce. These elevated levels of EI skills were more likely to help them cope with organizational stress, have less absenteeism and higher job satisfaction than those lacking in EI skills. "If the employee in a particular job has lower level of EI than that required by the job, he could find it difficult to cope with that job and also would be less satisfied with it" (Singh, 2003). In the current study, it was interesting to note that in comparison to other domains of EI, social management had higher correlation values across the 8 domains of organizational role stress indicating that lower the CSR's perception on empathy, service orientation and organizational awareness, higher the perceived role stress. This was clearly mentioned by Shetty, a supervisor in the study. According to him, "If the CSR's are not empathetic, they will not understand what the customer is going through and will become angry if the customer begins yelling at them. When this person encounters more than one such customer in a day, he gets frustrated and it adds on to his level of stress". Followed by the domain of social management, the Self management domain also had higher correlation values across some organizational role stress domains, indicating that lower the competencies of emotional self control, trustworthiness, conscientiousness, adaptability, optimism, initiative and achievement orientation, higher will be the role expectation conflict, role overload, personal inadequacy and resource inadequacy. In a working study by Dean and Rainne (2004) the recruiters of CSR's mentioned, "We're looking for flexible people: flexible emotionally, flexible intellectually, and flexible with their time, in other words, someone who's generally flexible and who's able to go with the flow, and who knows, to adapt!" Only then can they cope with the changing environmental conditions, varied range of clientele etc which they perceive as causing role stress. Also according to Freedman, "Optimism is the key. In a highly stressful job of a service provider, one needs to keep up his/her positivity and zest!" The responses on the interviews with CSR in the study revealed they found the job of CSR as very stressful and the reasons attributed to stress were lot of workload, there is less/no time for self and socializing, not enough training given to do the role, no growth opportunities, constantly keeping up to the changing demands of the customers etc. They also indicated that having emotional skills is very important as only then the CSR would be able to handle the demands and pressures of the job.

Thus, the findings of the study has a clear implication for the organizations. It is highly essential for service sectors like Customer Service jobs as it requires constant interaction with fellow human beings. Thus, its important for the Organizations to offer their employees a combination of EI and stress management training that would provide their employees additional necessary skills to deal effectively with the job requirements and carry out the role more effeciently. Role stress in a job like that of a CSR, is inevitable. But it can be reduced by helping the employees develop and use their emotional intelligence competencies. It is important for organizations to provide training to the CSR's, in order to increase their personal and social emotional skills like adaptability, optimism, emotional self control, conflict management, communication, building bolds etc which would in turn help the CSR to deal with abusive clients, monotony, routines, 
aggressive customers- which are an inevitable part of his role. This would help to reduce the CSR's role stress which would result in increased efficiency, thus contributing to the profit of the organization at large.

\section{References}

[1] Are You a People Person? The Call of Customer Service Jobs, Retrieved on August 4, 2010 from http://ezinearticles.com/?Are-You-a-People-Person?-TheCall-of-Customer-Service-Jobs\&id=4796874.

[2] Babu,(2008),Stress, Trauma, Anxiety, Fears and Psychosomatic Disorders Retrieved on February 11, 2012. from http://www.psychologicalselfhelp.org/Chapter5.pdf

[3] Beaujean, Davidson, Madge (2006). The 'moments' of truth in customer service, The Mc. Kinsey Quaterly, 2006, Number 1, pg. 64-73, Retrieved February 17,2012 from http://www.mckinseyquarterly.com/The_moment_of_truth

_in_customer_service_1728.

[4] Brown.L., (2011). What's love got to do with it? (Customer service that is.),business \& finance. Retrieved on february 19, 2012 from http://www.examiner.com/customer-service-innational/what-s-love-got-to-do-with-it-customer-servicethat-is.

[5] Brown.L., (2012). What the Apple Store does right, business \& finance. Retrieved on february 19, 2012 from http://www.examiner.com/customer-service-in-national/

[6] Boyatzis.R.,(1982). Emotional, social and cognitive intelligence competencies distinguishing effective Italian managers and leaders in a private company and cooperatives.Journal of Management Development, Vol. 28 Iss: 9 , p. $821-838$

[7] Coleman, G. (2008). Dealing with Stress with Emotional Intelligence. Retrieved January 23, 2008 from http://servicestrategies.com/blog/people-programs/dealingwith-stress-with-emotional-intelligence/

[8] Coscia (1996) \& D'Ausilo (1997) as cited in Role stress in call centers: Its effects on employee performance and satisfaction, 2001

[9] Darnell, B. G.(2011) The People-Profit Connection: How Emotional Intelligence Can Maximize People Skills and Maximize Your Profits (3rd Edition), BDI Publishers · ATLANTA
[10] Dean and Rainne, (2004). Absenteeism from the frontline: explaining employee stress and withdrawl in a call centre, Working paper $71 / 24$

[11] Goleman, D. (1998). Working with emotional intelligence: New York: Bantom Books. http://asbbs.org/files/2009/PDF/R/Rooprai.pdf

[12] Kumar Mangalam Birla, Times of India, 22 January, 2012

[13] Kumar, D. \& Hasnain N. (2009)Emotional Intelligence in Relation to General Health Among Customer Care Executives in Call Centres, Delhi Psychologist- Journal of Psychological Research, Vol. 1, No. 2,pp. 31-38

[14] Oginska et al., (2005) as cited in RoopRai and Kumar, Role of Emotional Intelligence in Managing Stress and Anxiety at workplace, Volume 16 Number 1, February (2009)

[15] Oginski.et.al, 2005

[16] Pareek, U. (1997), Handbook of Instruments for HRD and Training, New Delhi, Tata-Mcgraw-hill.

[17] R. Boyatzis and D. Goleman,(2007) The Emotional Competency Inventory, Boston: Hay Resources Direct, 2001. Retrieved July 22, 2007 from http://gbr.pepperdine.edu/031/eq.html\#note)

[18] RoopRai and Kumar, (2009). Role of Emotional Intelligence in Managing Stress and Anxiety at workplace, Volume 16, Number 1.

[19] Salovey, P. \& Mayer, J.D. (1990). Emotional intelligence, imagination, cognition \& Personality, 9, 185211.

[20] Singh.D. (2003) Emotional Intelligence at Work

[21]http://davefleet.com/2009/01/customer-service-ispublic-relations/, Retrieved on $16^{\text {th }}$ February, 2012

[22] http://www.brainyquote.com/quotes/authors/ d/daniel_goleman.html

[23]http://www.outsource2india.com/services/customer_int eraction_services.asp

[24] http://www.donnaearltraining.com/Articles/ StressManagementTips.html

[25] http://www.consumercourtforum.in/ f49/complaint-against-reliance-communication-theircustomer-care-dept-16477/ 